\title{
doispontos:
}

\section{O a priori político de Merleau-Ponty e Lefort}

\author{
Luiz Damon Santos Moutinho \\ Professor do Departamento de Filosofia da UFSCar \\ luizdamon@yahoo.com.br
}

Resumo: Uma investigação sobre “a judicialização da política e a politização do judiciário" restrita ao bom funcionamento do "Estado de Direito" se veria presa dos prejuízos que a própria ideia de "Estado" acarreta, consubstanciados na teoria que lhe dá suporte, a teoria da soberania. É preciso escapar ao "estadocentrismo" e um dos modos de fazê-lo é investigar as noções de "poder" e de "direito". Neste artigo, investigamos essas noções em Merleau-Ponty e Lefort. Palavras-chave: Poder; Direito; Democracia; Merleau-Ponty; Lefort.

\begin{abstract}
An investigation into "the judicialisation of politics and the politicisation of the judiciary" restricted to the proper functioning of the "rule of law" would be prey to the damage that the very idea of the "State" entails, embodied in the theory that supports it, the theory of sovereignty. It is necessary to escape "state-centrism" and one of the ways to do so is to investigate the notions of "power" and "law". In this article, we investigate these notions in Merleau-Ponty and Lefort.
\end{abstract}

Key-words: Power; Law; Democracy; Merleau-Ponty; Lefort. 
"Judicialização da política e politização do Judiciário". O tema aponta para uma indesejada confusão entre domínios que deveriam, em princípio, permanecer distintos: de um lado, o domínio da política, nos âmbitos dos poderes Executivo e Legislativo; de outro, a justiça, no âmbito do sistema Judiciário. Mas, claro, ninguém ignora que, de um lado, decisões naqueles dois primeiros níveis devam ser conformes à legalidade estatuída ou conforme a ordem constitucional. Por isso mesmo, a "judicialização da política" não significa que a política, em princípio, não deva ser conforme à lei, mas, ao contrário, significa que, não o sendo, o sistema judiciário pode ser chamado a intervir e - esse é o ponto - tomar decisões no lugar dos atores políticos. De outro lado, ninguém ignora, tampouco, que decisões dos tribunais são também "políticas", mesmo quando se restringem à norma. Por isso mesmo, a "politização do judiciário" não significa que as decisões do judiciário deixaram de emanar da pura norma, mas, ao contrário, que elas agora intervêm na produção e execução de leis. Quer dizer, ninguém ignora que os domínios não formam dois reinos à parte, e isso mesmo quando esse "Estado de Direito" não foi ainda corrompido. No entanto, apesar disso, uma diferença ainda persiste, pois é dela que provém a separação dos domínios: a diferença entre o domínio da política e o da justiça - e que, no limite, remete à diferença entre o poder e o direito. Ou ainda: a imbricação e a diferença entre os domínios da política e da justiça remetem às relações entre poder e direito: é a essas que finalmente devemos voltar a nossa atenção, e não tanto ao funcionamento daquilo que é nelas apoiado: menos que à operacionalidade do "Estado de Direito", trata-se de voltar àquilo que lhe é anterior.

Comecemos então por suspender o "estadocentrismo" e a teoria que lhe dá sustentação, a teoria da soberania. Desde sempre, a teoria da soberania, em suas variadas formas, procurou legitimar o poder, isto é, estabelecer um vínculo interno entre poder e direito. Ora, ao fazer isso - nota, por exemplo, Foucault -, ela "dissolve" "o fato da dominação", dando lugar, de um lado, aos "direitos legítimos da soberania" e, de outro, à "obrigação legal da obediência" (FOUCAULT 2001b, p.177 e FOUCAULT 2005, p.31). Foucault vai procurar fazer o "inverso" disso, deixando valer, de um lado, "o fato da dominação" e, de outro, o do "assujeitamento". Ou, dito de outro modo, vai deixar valer o poder sem buscar qualquer legitimação ou obediência. Evidentemente, no universo foucaultiano, isso vai exigir certas "precauções de método" (FOUCAULT 2001b, p.178), e curioso que é precisamente - ou sobretudo - diante e contra a teoria da soberania que Foucault as explicita. Não é o caso aqui de seguir a redução foucaultiana até fazer ressaltar a questão do poder. Por ora, vale notar que essa questão não pode ser colocada enquanto não se desfizer o nó da legitimidade acarretado pelo modelo da soberania: será preciso "cortar a cabeça do rei" (FOUCAULT 2001a, p.150), o que, assegura Foucault, "ainda não foi feito na teoria política” (FOUCAULT 2001a, p.150). Ou poderíamos dizer ainda: será preciso afastar o Estado, pois Estado e soberania andam juntos: "colocar o problema [do poder] em termos de Estado é ainda colocá-lo em termos de soberano e soberania e em termos de lei” (FOUCAULT 2001a, p.151).

Desfazer o nó que legitima o poder é também um passo da démarche de Lefort. No seu caso, esse nó aparece desfeito pelas revoluções modernas e a consequente emergência das "sociedades democráticas". Poder e Direito se "desintrincam", segundo o vocabulário lefortiano; e, por contraste, nas sociedades pré-modernas (o contraponto mais desenvolvido é com o Antigo Regime), eles apareciam "intrincados": diferentes, porém "intrincados". De onde vinha esse "intrincamento"? Ele é menos resultado do discurso político - no caso, da teoria da soberania -, de práticas políticas, do que de uma certa dimensão "simbólica" a partir da qual a sociedade do Antigo Regime se representava a si mesma. Lefort faz jogar aqui um "simbólico" que suporte aquele "intrincamento". Isso significa que a sociedade política como um todo quer dizer, o polo do poder, a posição das classes, dos grupos sociais, a diferenciação interna -, tudo isso guarda referência a um foco extrassocial, é mediado precisamente por referência a esse foco, a esse foco "divino". No Antigo Regime, o teológico e o político são inseparáveis, o que significa dizer que o poder 
(do rei) já se encontra referido e fundamentado por tal mediação, portanto, legitimado; ou seja, Poder e Direito estão "intrincados". O modelo rezava então que, nessa referência, o corpo do rei é "duplicado", um "corpo místico" duplica seu "corpo natural", à maneira do corpo de Cristo. E porque é assim duplicado, tanto "o direito parec[e] consusbtancial à pessoa do príncipe" (LEFORT 1983, p.53) quanto o poder aparece "incorporado no príncipe" (LEFORT 1991, p.28): ainda que o príncipe estivesse submetido ao Direito, pois a "origem [do Direito] se encontrava em Deus ou na Justiça", a verdade é que seu poder não conhecia "limites de fato" (LEFORT 1983, p.53). Ora, ao suprimir precisamente a referência ao divino, ao suprimir essa dimensão "simbólica", as sociedades modernas "desintrincaram" Poder e Direito, suprimiram a legitimidade intrínseca do poder e abriram assim um conjunto de questões desconhecidas do discurso político clássico. Que horizonte se abre aqui? Como em Foucault, também se abre a questão do poder. Mas, com ela, também a "dominação" e o "assujeitamento"? Não exatamente. Pois a redução lefortiana, ao preservar uma dimensão "simbólica", impede tornar o polo do poder o polo exclusivo da constituição - ou da produtividade. E, por isso mesmo, o direito não poderá se reduzir àquilo de que lança mão o poder, a "procedimentos de sujeição": "o sistema do direito e o campo judiciário são o veículo permanente de relações de dominação, de técnicas de sujeição polimorfas. O direito, é preciso examiná-lo, creio eu, não sob o aspecto de uma legitimidade a ser fixada, mas sob o aspecto dos procedimentos de sujeição que ele põe em prática" (FOUCAULT 2005, p.32). Vejamos por outro viés como essa mesma questão do poder se abre a Lefort.

\section{II}

Para ressaltar essa questão, parto de uma dificuldade apontada por Merleau-Ponty ainda nos anos 40, no pós-guerra, logo depois da publicação de Humanismo e terror. Merleau-Ponty teria notado - isso em um texto clarividente sobre Maquiavel, de 1949 - que a questão do "poder" estava em aberto: a experiência soviética, àquela altura, já desautorizava a hipótese de uma "solução", que seria uma "relação absolutamente nova entre o poder e os súditos" (du pouvoir aux assujettis) - em que, se não "anulado", o "poder" seria ao menos "controlado". Ora, essa promessa da revolução se revelou um fiasco, garante Merleau-Ponty: o "poder revolucionário" terminou por se "autonomizar", constituindo, assim, uma "camada dirigente" e "sem controle" (MERLEAU-PONTY 1985, p.281-2).É nesse contexto que ele sugere a releitura de Maquiavel.

Por que Maquiavel? A razão mais imediata é que também ele - como, de resto, Marx - coloca o problema do "poder" não em termos de "princípios" - sejam eles religiosos, cosmológicos, metafísicos, racionais mas interroga o poder "em operação". Marx enfrenta o problema - na avaliação, digamos, fenomenológica, de Merleau-Ponty - indo diretamente à "situação" e ao "movimento vital" dos homens mais explorados e oprimidos; teria buscado ali o "fundamento de um poder revolucionário, isto é, capaz de suprimir a exploração e a opressão" MERLEAU-PONTY 1985, p.281). Ora, também Maquiavel busca a "verdade efetiva da coisa", segundo o célebre enunciado do capítulo 15 de $O$ príncipe, e não subsume a política a princípios transcendentes nem pretende fundar o Estado ou a sociedade civil num contrato.

Mas agora, diante de Marx, a diferença parece estar ainda em outro lugar: Maquiavel pensa o conflito sem a alternativa da "solução", isto é, sem o fim da dominação. Em Marx, ao contrário, a questão do poder político permanece, no final das contas, obliterada, na medida em que ele aparece inteiramente reduzido a conflitos sociais, e por isso mesmo a promessa da revolução é a de uma sociedade política livre da dominação, sem referência a um poder em separado. Em Maquiavel, o poder político é irredutível, e vem daí que sua obra seja convocada na busca de uma "clareza política". Tudo se passa como se MerleauPonty quisesse guardar distância não apenas da política revolucionária, mas também daquele "mito" tão expandido no século XIX, nos termos de Lebrun, e do qual participam liberais e marxistas: o de uma sociedade autorregulada, que afaste portanto o poder político; segundo esse "mito", "o poder conhecia a sua decadência e começara a sua agonia" (LEBRUN 1981, p.9). Ou, noutras palavras, Merleau-Ponty 
desembarca da canoa da revolução, que vê no proletariado a encarnação do universal, reativando um tema clássico do pensamento político - o poder.

No pequeno texto sobre Maquiavel, Merleau-Ponty apenas aponta uma direção de pesquisa. E é precisamente essa direção que Claude Lefort seguirá nos anos seguintes.

Qual é a questão para Lefort? Aquela que será sempre a sua questão: a busca dos "princípios geradores do social", a "forma" do social, o da "instituição do social". São expressões que ocorrem no começo e no fim de sua carreira (veja-se, por exemplo, "A questão da democracia" (1983)), como também foi a questão da fase intermediária, a maquiaveliana: Maquiavel não será para Lefort o pensador do realismo político, da razão de Estado etc, mas o pensador da fundação do Estado, da "fundação incessante". Ora, nessa fase inicial, independentemente da resposta, da variedade de respostas a essa questão fundamental, do caráter tateante e errático, já aparece ali um elemento que vai colocar sérios problemas logo adiante: é que essa fundação, apesar de pequenas variações nas respostas, terá sempre a práxis social como seu ponto de fuga. Não é um equívoco denominar esse período, como o faz Poltier, como o de uma "fenomenologia do social".

Mas se o início de sua carreira pode ser assim descrito, é verdade também que, ainda nos anos 50, e ao longo dos anos 60, Lefort leitor de Maquiavel dá início a uma autocrítica e a uma revisão de algumas categorias básicas de seu pensamento. O núcleo da transformação me parece ser justamente o aparecimento de uma concepção estritamente política do poder - o que significa o abandono do modelo anterior, marxizante, fortemente assentado na "produção". A "dominação", de natureza política, não se explica apenas por relações econômicas. Naquele início, a busca pelos "princípios geradores do social” se resolvia com a "praxis" - sem referência ao "poder". Havia então uma "experiência constitutiva da sociedade" (LEFORT 1979, p.33; grifos nossos). O que vai aparecer logo depois com muita clareza - e isso já na grande obra sobre Maquiavel - é o esboço de uma "ontologia política" (LEFORT 1979, p.368 e p.426), assentada no primado do "político". A reviravolta aí, para o nosso interesse, é o apelo a uma noção de "simbólico" capaz de ultrapassar os prejuízos do primeiro modelo - "simbólico" que, no Antigo Regime, atava o teológico ao político e que, nas "sociedades democráticas" terá outra configuração. A dimensão "constitutiva" do primeiro modelo era uma práxis, um ato. Haverá um descentramento: é a práxis social que se compreende a partir do "simbólico", qualquer que seja ele, não o inverso.

No que nos concerne aqui, a volta a Maquiavel representou para o jovem Lefort um projeto de trabalho cujos termos Merleau-Ponty anunciava no seu ensaio de 1949: 1) pensar o político por ele mesmo, não só, como faz Maquiavel, sem referência à teologia e à cosmologia, mas ainda (e aqui reside a autocrítica, a superação da "fenomenologia do social") sem apoio no social: o poder não será projeção de relações sociais; daí o primado do político; com algumas variações, algo análogo também se passa com MerleauPonty na virada dos anos 40 para os anos 50;2) pensar outra noção de conflito, sem "solução" para o "problema social". E, tal como para Merleau-Ponty, também aqui o proletariado deixa de encarnar o universal, aquela classe que poria fim às classes, inclusive a si mesma como classe; realizando o universal, ela poria fim, portanto, à sociedade dividida. Findo o universal, abre-se agora outro horizonte, em que o conflito se afirma irredutível. Eis aí, em linhas gerais, os termos de ambas as autocríticas; com elas, desaparecem a arkhê e o telos.

\section{III}

De sua parte, fazendo sua autocrítica em As aventuras da dialética, Merleau-Ponty nota que ele ainda permanecia, até Humanismo e terror, no terreno da moral: se o proletariado aparecia-lhe como encarnando a negatividade, portando o universal, não era porque a lógica do capital levaria a uma oposição das classes, unificando o proletariado no antagonismo à classe burguesa; antes disso, ele era o portador do 
universal porque era privado da particularidade do interesse, e assim sua ação fazia "passar" o valor: era o proletariado que permitia escapar ao humanismo abstrato e "realizar" a "humanidade". Havia, portanto, uma função axiológica na prática proletária; assim, a política merleaupontiana ainda era governada pelo $a$ priori da moralidade: "não estávamos no terreno da história (e do marxismo), mas no terreno do a priori e da moralidade (...) não era a filosofia da história, era Kant sob um disfarce" (MERLEAU-PONTY 2000, p.321). A crítica vai incidir não sobre a dialética, mas sobre a ideia de que uma classe possa encarnar a dialética, portar em si o universal. Ele vai traçar então uma análise que remonta a Weber (como modelo do "entendimento"), passa pelo marxismo vigoroso de Lukács (dos anos 20), por Lenin, Trotsky e, finalmente, Sartre, num percurso que ele denomina "as aventuras da dialética". Essas aventuras vão culminar, ali por volta dos anos 50, segundo diagnóstico de Merleau-Ponty, num marxismo ossificado e numa práxis revolucionária dogmática e voluntariosa. Qual o ponto culminante dessa crítica?

Parece-me ser a crítica da história teleológica, história regulada por leis rigorosas (ou, pelo menos, leis da forma social histórica baseada no modo de produção capitalista) e, ligada a essa, a crítica da política revolucionária. Vai resultar daí: 1) não a recusa da história, mas da teleologia: recusando o telos, o que surge é uma história "plural", uma variedade de "planos ou ordens"; 2) não o fim da dialética, mas da ideia de que uma classe possa encarnar a dialética, portar em si o negativo, como crítica encarnada, ser supressão da sociedade de classes e supressão de si como classe, ser crítica e autocrítica (MERLEAU-PONTY 2000, p.320). Agora, "oposições", "contrariedades", "devires", “diferenças", "ultrapassamentos" são localizados, envolvem plano previamente instituído e são incapazes de revolver esse todo comum que os envolve (MERLEAU-PONTY 2000, p.281-2). O que Merleau-Ponty rejeita agora é a ideia de uma significação total da história, de que a história organize ela mesma sua própria recuperação; de que uma crítica possa implicar a contestação de si mesma, ser crítica por dentro, ser "revolução permanente"; a revolução como "ação absoluta" é ainda um conceito governado pelo a priori moral. A conclusão das Aventuras... leva Merleau-Ponty ao elogio do liberalismo de Weber, um "liberalismo heroico" porque "faz entrar em seu universo aquilo que o contesta” (MERLEAU-PONTY 2000, p.312-3) - e, portanto, restringe o poder absoluto. O liberalismo de Weber, diz Merleau-Ponty, "não postula um empíreo (empyrée) político, não toma por absoluto o universo formal da democracia, ele admite que toda política é violência, mesmo, a seu modo, a política democrática. Seu liberalismo é militante, sofredor mesmo, heroico, isto é, ele reconhece o direito de seus adversários" (MERLEAU-PONTY 2000, p.41).

Daí que o "novo liberalismo" a que chega Merleau-Ponty queira conservar em mãos as "duas pontas da cadeia": de um lado, o "problema social", a luta de classes ("pois há classes"); de outro, a "liberdade" (se outra política "puder passar", outra que não a liberal - mas também outra que a revolucionária: colocando o "problema social em termos de luta", é preciso ainda "recusar a ditadura do proletariado" (MERLEAU-PONTY 2000, p.313)). Serão esses os marcos de uma "esquerda não comunista", anunciados por Merleau-Ponty, ali naqueles anos 50. A luta será vista então como "localizada", incapaz de revolver toda a história. Comentando a política merleaupontiana, Lefort a denomina "política de contestação", mais radical que a de Marx... E por que ela seria mais radical? Aparentemente, por isso mesmo, porque, não visando mais a uma totalidade, a luta não teria termo, e assim ela se generalizaria: ela se tornaria permanente, sem rima nem solução. Que isso implique em maior "radicalidade", parece uma contradição, pois, justamente, ela deixou de visar a totalidade... A autocrítica de Merleau-Ponty, segundo Lefort, vai de par com aquela outra, em que ele já não busca "igualar a reflexão à vida irrefletida da consciência", já não busca mais a "ficção de uma coincidência de direito entre o Ser e o pensar" (LEFORT 1978, p.122), o que ele ainda faria no período da Fenomenologia da percepção. É depois dessa autocrítica que ele se abre finalmente (embora tivesse desde sempre um tal projeto) à indeterminação: "a ideia de um pensamento consagrado à indeterminação e de uma política consagrada à contestação", eis aí Merleau-Ponty, segundo Lefort. Importa agora notar que é desenvolvendo a ideia de que esse meio em que vivemos, em um tempo e em uma sociedade, esse "meio da história", de que esse meio carrega em si mesmo, em sua "estrutura", 
uma "indeterminação", que, finalmente, deve ser restituída "no quadro de seu próprio simbolismo" (LEFORT 1978, p.103), é por aqui que Lefort já desliza do pensamento de Merleau-Ponty para o seu próprio. A "indeterminação" de Merleau-Ponty - veremos adiante sua consequência política deve ser lida à luz de um "simbolismo" de que Lefort quer dar conta em sua "filosofia política".

IV

O simbolismo lefortiano já aparecia em sua leitura de Maquiavel. Já ali uma imagem do príncipe é projetada para além do conflito que opõe os grandes e o povo, imagem que assegura unidade à sociedade dividida. Apenas nesse momento a força se converte propriamente em poder político, e como condição da unidade do principado. Já ali, portanto, Lefort havia abandonado os motivos sociais de sua primeira fase e apontava, para além da luta social, para uma dimensão política irredutível.

Mas é só na última fase que ele vai desenvolver sua teoria da "democracia" e o "simbólico" implicado por ela. O que é inédito na democracia é que, enquanto na sociedade do Antigo Regime o corpo do rei agia como mediador entre o visível e o invisível, entre o visível e o Outro mundo, e assegurava, assim, à sociedade a representação de sua própria unidade, numa figuração imaginária do "simbólico", na democracia, ao contrário, desaparece a figura de mediação. É isso que Lefort chama a "desincorporação do poder"; permanece o lugar do Outro, mas permanece como um lugar vazio. Esse é o núcleo da "revolução política" moderna - ou, se se quiser, a emergência da modernidade não está, como pensa o jovem Marx, na "emancipação política", ou antes, na "ilusão política", na cisão entre o "político" e o "social", entre o "cidadão" e o "burguês", entre o universal e o particular, consequências, pensa Marx, do "parcelamento dos interesses privados", da "emancipação da sociedade burguesa" (LEFORT 1983, p.52). O núcleo da revolução moderna está na mutação do simbólico, e isso impõe uma compreensão do "político" para o qual Marx esteve "cego". Que mutação é essa?

Seu núcleo é a "desincorporação" "simultânea" (LEFORT 1983, p.53) do poder e da sociedade - e aqui Lefort retira as consequências de sua leitura da "indeterminação" a partir de uma "dimensão simbólica". A uma transcendência que já não pode ser figurada imaginariamente, a um "lugar vazio", corresponde uma sociedade sem corpo (LEFORT 1991, p.34), impossível de ser circunscrita (LEFORT 1983, p.54).

Do lado da sociedade, não se trata, então, para Lefort, da emergência da "sociedade civil", sociedade atomizada em função dos interesses privados, definida, portanto, a partir de uma determinação econômica. Daí porque ela não será nem a sociedade unificada pelo Soberano, nem a sociedade "espontânea", resultado não mais de um contrato, mas de um acordo "natural", à maneira da matriz liberal escocesa (Ferguson, Hume, Smith). Essas são duas maneiras diversas de visar o problema, uma buscando a constituição da sociedade por alto, outra, por baixo. A sociedade lefortiana não tem nenhuma determinação, ela é "puramente social" (LEFORT 1991, p.34), ela é "indeterminada".

Do lado do Poder, o "Povo" parece ser a instância de unificação. Mas esse "Povo" substancial não é passível de circunscrição, não é delimitável, ele é igualmente indefinido; quando ele é chamado a se manifestar, como em eleições, por exemplo, ele deixa de ser "substância" para ser "número" (LEFORT 1991, p.34). Nesse caso, o "Povo" é "indeterminado" e justamente por isso o lugar do Poder permanece inocupável. Ora, vale perguntar: essa não é uma simples diferença entre Povo como "corpo político", portanto, "constituinte", e "povo real", o povo que vota? Por que essa diferença óbvia suprimiria a soberania popular? Essa diferença já se encontra em Rousseau: não é o "povo real" que legisla, mas é preciso a "vontade geral" para conferir autoridade à lei; sendo ela universal na origem, pela vontade geral, ela deverá valer pra todos: a lei geral tem por origem a vontade geral. Ora, acontece que a unidade "Povo" é então forjada por meio de um contrato, o que supõe um vínculo interno entre o "poder" e o "direito", 
vínculo que assegura a tal "povo soberano" a fonte da legitimidade. O "lugar vazio" de Lefort, por sua vez, não se limita a mera impossibilidade de figurar o Poder; é ainda o esforço de "desintrincar" poder e direito - e assim tornar aberta a questão da legitimidade do poder. Por isso mesmo, não há em Lefort "poder soberano" nem fundamento normativo: é que, "desincorporado" o poder, o direito perde seu "ancoradouro" (LEFORT 1983, p.54). A democracia lefortiana é sem demos e sem fundamento.

Diz Lefort: "O essencial, a meu ver, é que a democracia institui-se e se mantém pela dissolução dos marcos de referência da certeza. A democracia inaugura uma história na qual os homens estão à prova de uma indeterminação última quanto ao fundamento do Poder, da Lei e do Saber, e quanto ao fundamento da relação de um com o outro, sob todos os registros da vida social" (LEFORT 1991, p.34; grifos nossos em "indeterminação última").

\section{V}

Merleau-Ponty e Lefort têm um mesmo horizonte político em vista: a crítica da política revolucionária marxista, de um lado, e do "totalitarismo", de outro. Esses são, para ambos, os grandes acontecimentos políticos que se impõem ao pensamento. Embora Merleau-Ponty não tenha desenvolvido a crítica do “totalitarismo", ela já está em germe na sua crítica da revolução, até mesmo no ambíguo Humanismo e terror. $\mathrm{O}$ que, em contrapartida, parece se abrir a ambos é o horizonte de uma democracia que institucionalize o conflito (LEFORT 1991, p.32). Em ambos, a redução que abre a questão do poder conduz não à "dominação" e ao "assujeitamento", mas ao conflito, e Maquiavel é a referência dominante: foi o conflito entre o povo e os grandes que fez a grandeza de Roma, lembram ambos. Esse conflito se mostra mais variado do que o da "luta de classes": assim, a sociedade que se abre, em ambos os casos, é mais ampla, diversificada e fragmentada que a sociedade civil burguesa e sua matriz econômica de classes. E, com a extensão do conflito, abre-se uma nova concepção de poder: não mais intrinsecamente legitimado - seja, no caso de Merleau-Ponty, não mais o poder revolucionário que portaria em si o universal; seja, em Lefort, um "poder democrático" que é "desintrincado" do direito, isto é, que está permanentemente em questão quanto a sua legitimidade, que, portanto, deve buscá-la sempre, pois já não a porta em si.

E, assim, o problema se transforma: se não se trata mais de um poder que porte a verdade, tampouco se trata de pura força: "nem puro fato, nem direito absoluto" (MERLEAU-PONTY 1985, p.269), "os homens deixam-se viver" sob sua dominação, mas, ultrapassado certo limite, eles se dão conta de que ele é injustificável (MERLEAU-PONTY 1985, p.269), diz Merleau-Ponty em sua leitura de Maquiavel. Há certo limite que o poder não pode ultrapassar, aquele que leva ao desprezo e ao ódio dos súditos, mas, afora isso, o poder goza de um assentimento "tácito": "o poder não coage, não persuade: ele envolve - e envolve-se melhor apelando à liberdade do que aterrorizando" (MERLEAU-PONTY 1985, p.269). São as lições que Merleau-Ponty retira de Maquiavel e que agora, diante de um poder que não é mais "justo", desloca a questão política: não se trata mais de buscar uma política que realize o universal, que realize a verdade (e que Merleau-Ponty entende agora como uma moralização da política), mas uma política que não seja injusta (MERLEAU-PONTY 1985, p.269). Trata-se, portanto, de uma política que perdeu do horizonte o "absoluto", o "justo", a "verdade". Assim, a perspectiva do conflito impõe que também a crítica "se confronte sempre com o juízo de uma oposição" (MERLEAU-PONTY 2000, p.312), que a crítica que denuncia as "taras do capitalismo", não esteja "comprometida com um absoluto de negação" (MERLEAUPONTY 2000, p.320-1). A crítica merleaupontiana do poder consiste então em dissolver a miragem do poder absoluto e fazer o elogio do conflito: aparentemente, só um poder restringe outro poder, só a luta pode assegurar a república: "a história é uma luta e se as repúblicas não lutassem elas desapareceriam" (MERLEAU-PONTY 1985, p.279). 
Quanto a Lefort, a tese do "simbólico" o leva a outras conclusões: que o lugar do poder seja um lugar vazio, isso, garante ele, "impede aos governantes de se apropriarem do poder" - Lefort é mais preciso: "de se incorporarem no poder" (LEFORT 1991, p.32; grifos meus). Ora, que isso significa? A um poder que já não pode ser legitimado, o "lugar vazio" indica idêntica restrição de poder, como em Merleau-Ponty? Vejamos isso de perto a partir de algumas pistas de investigação.

\section{V.a}

A primeira pista diz respeito ao político (ou ao a priori político). A crítica do poder revolucionário, em Merleau-Ponty, se fez no contexto de uma crítica da filosofia da história: é a reforma dessa, como história plural e não mais como totalização em curso, que torna possível a critica do poder revolucionário. A "instituição" como "meio da história" veio marcar esse descentramento da ação - ou da revolução -, ação que faz, mas que também éfeita, em contrariedades, oposições, diferenças locais. Em Lefort, ao contrário, toda ação se faz no interior de uma dimensão "simbólica" que, ela, não muda. O "simbólico" de Lefort está além, ele é uma Alteridade. Por isso mesmo, não haverá o vaivém da ação-passividade de Merleau-Ponty, ou o que ele chama "reversibilidade": quando toco, sou tocado; quando ajo, sou "agido" etc; ao contrário, o simbólico é o "inamovível na história" (NEVES 2016, p.127). Ora, mas isso não é o mesmo que retirar da ação humana o papel de agente histórico? (NEVES 2016, p.127).

Essa questão cabe mais a Lefort do que a Merleau-Ponty. No entanto, para ela ser bem avaliada, é preciso notar que a representação da história plural de Merleau-Ponty é ainda parcial: Merleau-Ponty não é, como pensa Lefort, um "relativista". Se desaparece a ideia de uma totalização em curso, de um revolver a história por inteiro, não desaparece a ideia de uma totalidade. Grosso modo, a nova filosofia da história traz uma ideia de totalidade que não é mais resultado de uma síntese e que seria assim algo como o "inamovível". Mas com uma diferença crucial: enquanto em Merleau-Ponty essa totalidade é um "elemento" comum (no sentido em que se dizia: a água, o fogo são elementos) - no vocabulário de Merleau-Ponty, a carne, aquilo que me vincula ao mundo e aos outros corpos, aquilo que tudo vincula -, em Lefort, esse terceiro termo é uma Alteridade, irredutivelmente outro. Ali onde Merleau-Ponty vê "simetria" e reversibilidade entre os sujeitos, todos vinculados a uma única "carne", e que permite pensar a atividade-passividade, Lefort vê antes o sujeito iniciado no mundo por um Outro: para além da relação fusional com a mãe, diz Lefort, o infante é confrontado com a mediação de um terceiro, que opõe a Lei a seu desejo. Há uma mediação análoga a essa que institui o social: é a "eficácia simbólica" que funda a sociedade política.

Ora, que seja "elemento comum" (Merleau-Ponty) ou "Alteridade" (Lefort), parece que não estamos mais em um plano de alcance da ação humana. No entanto, a ideia de reversibilidade modela outra noção de ação - ou, se quisermos, de "poder", e é isso que parece relevante aqui. Pois a ação-passividade permite pensar uma restrição ao poder implicada na própria relação de poder - ou ainda, permite pensar uma resistência. É essa relação de poder que Lefort parece perder ao apontar para um simbólico que denega, ele, a "incorporação no poder". Dou um exemplo do alcance dessa diferença: quando trata do Estado-Providência, Lefort o considera sob uma "dupla face", Estado-Providência e Estado-Guardião, uma iluminada, outra obscurecida. A questão se coloca assim: a expansão do Estado-Providência não faz revelar sua face oculta, "obscurecida", coercitiva? A crítica é bem conhecida, de liberais e não liberais. Para Lebrun, por exemplo, já os new human rights de Roosevelt nada tinham que ver com o "aprimoramento das liberdades individuais” (LEBRUN 2006, p.252 e LEBRUN 1981, p.87 e p.90), eles não fazem senão aumentar a potência do grande Leviatã: "o que a história nos ensina é que esses direitos [à vida, à felicidade, ao corpo, à saúde...] só podem ser satisfeitos à custa de um crescimento do poder estatal. Como analisar de outra forma, por exemplo, o socialismo sueco?” (LEBRUN 1981, p.92). Para Lefort, contudo, há algo que impede a expansão do Estado coercitivo, e isso é o "dispositivo democrático": "se o Estado-Providência não se torna um Estado-Guardião, a principal razão está em não ter um senhor. Surgisse um senhor, o Estado 
perderia a inquietante ambiguidade, que lhe é própria, na democracia" (LEFORT 1991, p.46; grifos meus). Assim, o que impede que o Estado-Providência se torne um Estado-Guardião, puro poder coercitivo, é uma razão negativa, e o problema se transforma em: o que impede a incorporação no poder; nesse caso, é um "simbólico" que torna o poder infigurável e o Estado, não assenhoreável. É sob essa condição que haverá, para além da face ambígua do Estado, "a emergência de reivindicações, de lutas por direitos" (LEFORT 1991, p.31); é por isso, igualmente, que Lefort pensa a resistência a partir de um direito, não, certamente, como um direito natural, mas ainda como um direito, agora afirmado na luta pelo próprio titular, dele inseparável (LEFORT 1991, p.49). Em Merleau-Ponty, a "reversibilidade" abre caminho para pensar uma relação de poder em que essa resistência é constitutiva da própria relação, sem remissão a um "simbólico". Em Lefort, essa remissão impede a "incorporação" e abre assim um campo de lutas.

\section{V.b}

Uma segunda pista diz respeito ao social (ou às "lutas sociais"). Passar à "instituição" não quer dizer passar à "forma estatal" em oposição à sociedade civil. Merleau-Ponty não coloca uma "forma política" para além da "luta social". A recusa do poder revolucionário, assim, não acarreta a passagem à democracia liberal, a um "Estado de direito". Por outro lado, a passagem à "instituição" implica a recusa de uma autodeterminação da sociedade e reconhece o conflito como definitivo. A forma política é assim inseparável da "luta social". E, no caso de Merleau-Ponty, pelo menos na hora em que anunciava sua política, a "luta social" era a luta de classes. Ora, o conflito social se esgota nessa forma econômica?

Lefort, por sua vez, parece dissolver, senão a luta de classes, pelo menos seu vínculo com o político. E a razão disso é, novamente, pensar a forma da sociedade a partir de um "simbólico" separado. Daí objeções como a de Ruy Fausto, por exemplo, que, embora por outras vias e chegando a conclusões diferentes das nossas, nota que a luta de classes desaparece do horizonte de Lefort. O tema de Fausto é a crítica de Lefort à leitura marxiana das Declarações em Sobre a questão judaica. Lefort aponta a "cegueira" de Marx em tomar as Declarações como um mero documento de consagração da sociedade burguesa e do "Homem", que não é outro senão o membro egoísta dessa sociedade. Marx "deixa-se aprisionar", diz Lefort, "pela versão ideológica dos direitos, sem examinar o que significam na prática, que reviravolta fazem na vida social”, sem atentar para "novo modo de acesso ao espaço público" (LEFORT 1983, p.46 e p.47). Ora, replica Fausto, mas "Lefort teria levado suficientemente em conta o lado egoísta-burguês das Declarações?" (FAUSTO 2018, p.212). Lefort teria visto nelas uma "dualidade", "mas quando ele se refere às tendências 'negativas' que podem aparecer no interior da democracia, ele as trata um pouco como se isso não fosse essencial. De fato, o que não vai na direção da democracia enquanto democracia, Lefort tende a ver como elementos da ordem da 'aplicação de fato' ou da 'elaboração de fato' das leis". Nesse caso, "a violência do capital" é tomada como "violência 'de fato', não inscrita na essência, ou no 'modo de constituição' da sociedade em questão" (FAUSTO 2018, p.212-3). Nesse ponto preciso, a crítica de Fausto é justa, e o motivo último é que o "simbólico" de Lefort é instância separada, ou uma Alteridade, o que o levou a separar conflito social e forma política; basta-lhe assegurar o "lugar vazio" do poder.

Ora, é esse salto, precisamente, que Merleau-Ponty não pode dar, o que se ressalta na oposição de Lefort, a partir do "simbólico" como "alteridade", à "carne" comum de Merleau-Ponty. Diferentemente de Lefort, Merleau-Ponty coloca o problema de saber de que natureza é esse vínculo entre o social e o político. Uma questão, então, se impõe: a investigação de Fausto consiste em pensar a "tensão" (FAUSTO 2018, p.212) entre capitalismo e democracia; no contexto do debate em torno das Declarações, entre "homem" (democracia) e "homem egoísta" ou interesse de classe (capitalismo). No entanto, o que parece mais interessante pensar é, não a "tensão" entre dois polos conflitantes, mas o político como forma do social, inseparável dele, menos "capitalismo versus democracia" e mais a democracia do capitalismo. 
Uma terceira pista de investigação diz respeito ao direito (ou à "política democrática"). Do "desintrincamento" entre poder e direito segue-se, em Lefort, a questão da legitimidade do poder, pois ele deixa de ser então intrinsecamente legítimo, e, do lado do direito, segue-se a questão do "ancoradouro" do direito, antes "consubstancial à (...) pessoa do príncipe" (LEFORT 1983, p.53-4). Mesmo reconhecendo que a monarquia se apoiou na teoria da soberania e que, por isso mesmo, "a dissociação da instância do poder e da instância do direito (...) estava no princípio do Estado monárquico", mesmo assim, Lefort não deixa de notar que "o poder do príncipe (...) não conhecia limites de fato" (LEFORT 1983, p.53). Foi só com a "revolução política' moderna" que a "desincorporação" do poder e do direito, e portanto aquele "desintrincamento", deixaram em aberto a questão do poder e do direito: o lugar do poder mostra-se vazio e sua legitimidade torna-se uma questão. E quanto ao direito? Todo o problema consiste em saber: quem, agora, diz o direito? "Agora" essa questão se coloca em um horizonte em que não há mais "povo soberano", quer dizer, nenhuma fonte de poder intrinsecamente legitimada. Quem tem "autoridade" para enunciar o direito?

A resposta a essa questão é dupla: ninguém, certamente, tem "autoridade" - isto é, poder legítimo para outorgar ou ratificar direitos. Exceto - eis o primeiro aspecto - se aquele que enuncia os direitos for o mesmo a quem pertencem os direitos. Mas isso, em um contexto sem direito natural, implica que, entre os direitos e a enunciação, não há a mesma relação - para retomar o bom exemplo de Flynn - entre a mesa ser vermelha e o ato de dizer que a mesa é vermelha: a vermelhidão da mesa é anterior a nossa predicação e não afetada por ela (FLYNN 2005, p.168). O direito de que fala Lefort, por sua vez, só emerge com a enunciação: ele não é apenas "o objeto de uma declaração, é de sua essência declarar-se" (LEFORT 1983, p.54). Ele só emerge na luta que o afirma. Mas isso - eis o segundo aspecto da resposta - conforme o modelo simbólico de Lefort: quer dizer, o direito se revela agora, ele mesmo, como "simbólico", aparece uma "dimensão simbólica dos direitos do homem", única capaz de se mostrar como "constitutiva da sociedade política” (LEFORT 1983, p.56; grifos meus). E é precisamente essa dimensão do direito que Foucault ignora. Ora, mas não dissemos que a sociedade democrática é aquela para a qual o lugar do poder é um "lugar vazio"? Certamente. Isso significa que o direito será para ela, à sua maneira, aquilo que o poder corporificado é para o Antigo Regime? A resposta a essa questão exige que se conheça de que maneira o direito "constitui" a sociedade política democrática.

Lefort mostra essa "constituição" em três momentos, que reproduzem, com alguma alteração, a dialética do tempo na Fenomenologia da percepção. Primeiro momento: aquele a quem pertencem os direitos é o Homem, não tal ou tal homem, mas todos os homens; aqui, o momento do Todo. Segundo momento: mas a sociedade democrática, precisamente porque é "privada da mediação de um poder incorporado", é "sem corpo". A imagem do Todo é então desfigurada, e é preciso dizer que os direitos são dos indivíduos, "soberanozinhos independentes, cada qual reinando sobre seu mundo privado" (LEFORT 1983, p.54). Aqui, o momento das partes. Terceiro momento: esta representação, como negação, destrói a anterior, "a de uma totalidade transcendente às suas partes", mas é também destruída por ela, fazendo "descobrir uma dimensão transversal das relações sociais": nesse caso, os indivíduos produzem relações sociais e são produzidos por elas, tiram delas sua identidade e também as produzem (LEFORT 1983, p.54; grifos meus). Aqui, o momento do Todo e das partes, ou, se se quiser, de uma "totalidade horizontal". E aqui aparece, finalmente, o caráter "constitutivo" do direito: ele constitui porque une, porque vincula: o direito meu acarreta direito teu. Mas - e esse é o ponto decisivo - ele une não apenas as partes, ele une as partes e o todo simultaneamente, ele une as partes ao todo, constituindo-os simultaneamente. É precisamente esse vínculo das partes ao todo, segundo uma dialética em que a parte implica o todo e o todo implica a parte, que faz sobressair uma dimensão de "transcendência", segundo o vocabulário ortodoxo da fenomenologia, e que Lefort, não sem algumas inflexões, chamará de "simbólico". O modelo do logos fenomenológico, em obra já na simples percepção, reza que não percebo os lados sem alcançar a coisa, pois os lados são 
lados de tal coisa, e que só alcanço a coisa por meio dos lados. Que se entenda bem: dissemos que a sociedade não se apreende como "unidade" senão mediada por referência a uma "transcendência" - ora, dessa feita, os deuses não estão aí, o "lugar" dos deuses permanece "vazio": nenhuma "transcendência", portanto, se afirma. Nenhuma, senão a da própria sociedade, sociedade que se põe agora não como um todo transcendente às partes, mas como um todo "transversal" implicado por elas, e que por isso mesmo é uma totalidade aberta, sempre por fazer. E, por referência a ela, inversamente, a sociedade "una" não é jamais bem constituída, no sentido em que a cisão interna ou o conflito interno não é jamais ultrapassado.

Daí, por exemplo, as objeções a Marx e sua tese do homem egoísta: mesmo o direito de opinião, Marx o reduz a um "equivalente espiritual da propriedade privada" (LEFORT 1983, p.43), não vê aí a construção de um "espaço público": "por exemplo, o direito de um de falar, escrever, imprimir livremente implica o de outro de ouvir, ler, conservar e transmitir a coisa impressa" (LEFORT 1983, p.54). Essa dialética modela uma figura da "universalidade" do direito que já não é idêntica a simples abstração - o que significa dizer que a totalidade aqui constituída não é um Homem abstrato, conforme aquela conhecida e fácil oposição entre abstrato e concreto: tal Homem, diz Marx, mas também Joseph de Maistre, não é esse, aquele, não é histórica e socialmente determinado etc; é uma pura ficção abstrata, dizem. Ora, abstrato aí é um vazio (nem francês, nem inglês...), ou - para mantermos a analogia - é a casa vista de lugar nenhum. No entanto, trata-se justamente de vincular parte e todo - não de separá-los; por isso, é a casa vista de todos os lugares, mesmo daqueles que uma parte pode ter de outra. O "homem" aqui é essa totalidade, totalidade que não é apenas "horizontal", mas, sobretudo, indeterminável, no sentido de indomável, de que cada direito enunciado produz relações e identidades que produzem novas relações, que demandam novos direitos ou novas reformulações... E é nessa medida que o "homem" pode ser o "ancoradouro do direito" e os "direitos humanos" podem se enunciar como "políticos".

Ora, na medida em que os direitos se afirmam como "constitutivos" da sociedade democrática - pois não apenas unem, mas constituem ainda essa transcendência aberta, indeterminada -, forma-se um "polo do direito", diante do qual, assegura Lefort, o poder do Estado tem que dar uma resposta, para evitar o risco de "abismar-se na trivialidade" (LEFORT 1983, p.62). Afinal, o Estado é um "poder de fato" às voltas com a questão da legitimidade, e a política dos direitos, ou "política democrática" (LEFORT 1983, p.69), é a política que carrega uma legitimidade, uma ideia do que é "socialmente legítimo" (LEFORT 1983, p.60). De onde vem essa "legitimidade"? Das "reivindicações", da "contestação", que recusam "legitimidade estabelecida", que testemunham "um sentido difuso de justiça” (LEFORT 1983, p.60). Pois, múltiplas, variáveis, nada parece unir as diferentes lutas por direitos - lutas das "minorias", por exemplo -, nada, exceto, precisamente, "a ideia de uma legitimidade" (LEFORT 1983, p.61). E é isso que finalmente atesta a "eficácia simbólica da noção de direitos" (LEFORT 1983, p.62): é esse vínculo entre a parte e o todo, é essa "combinação", essa "conjunção", "de uma maneira que parece paradoxal", entre " $a$ ideia de uma legitimidade e a representação de uma particularidade" (LEFORT 1983, p.61-2; grifos meus). A "parte", assim vinculada ao "todo", firma-se como "constitutiva", e assim se distingue do "interesse", na mesma medida em que o "simbólico" se distingue da "relação de força": ali, constitui-se um "todo"; aqui, as partes "chocam-se umas contra as outras" (LEFORT 1983, p.62). Ora, diante dessas lutas "inspiradas pelas noções dos direitos" (LEFORT 1983, p.63), é uma ilusão "reformista" supor que o Estado possa se fazer "o agente da mudança social e o promotor de um sistema cada vez mais igualitário" (LEFORT 1983, p.63). E por que o Estado não poderia fazê-lo? O Estado terminaria por "ocultar" "a pluralidade, a fragmentação, a heterogeneidade dos processos de socialização e igualmente o caráter transversal das práticas e das representações, o reconhecimento mútuo dos direitos" (LEFORT 1983, p.68) - e reporia o perigoso "culto da unidade" (LEFORT 1983, p.69), suprimindo, dessa vez, o conflito interno. Daí a necessidade, insiste o ex adepto da "autogestão", de "libertar da hipoteca que fazem pesar sobre elas [as lutas] os partidos que têm vocação para o poder" (LEFORT 1983, p.64). As lutas por direitos são, portanto, as lutas que podem tecer uma sociedade plural, heterogênea, indeterminada. Ora, mas se é assim por que 
tais lutas, portadoras de "legitimidade", não ocupam o "lugar vazio", o lugar do Poder das "sociedades democráticas"? Passa-se exatamente o inverso: elas são tornadas possíveis pela "forma democrática”; em lugar de preencher o "vazio", elas se nutrem dele; elas são uma possibilidade da "forma democrática", assim como também o é o "totalitarismo" - nesse caso, a de tentar colmatar a fenda social, enquanto as "lutas democráticas", ao contrário, preservam-nas, e exatamente por isso elas atestam "eficácia simbólica”, enquanto o "totalitarismo" abisma-se na violência.

Vimos que na autocrítica de Merleau-Ponty e Lefort a passagem por Maquiavel foi decisiva. Aparentemente, Merleau-Ponty reteve dela a exigência de assumir uma condição fática em que o poder não é jamais inteiramente legitimado. Que vale mais, por isso mesmo, buscar uma restrição ao poder do que a fonte de sua legitimação. A busca de uma "política que não seja injusta” - não é isso que determina o a priori político de Merleau-Ponty? E isso não a distancia da "política democrática" de Lefort, assentada no "sentimento difuso de justiça”? Não há aí uma diferença de a priori político?

No entanto, se é verdade que a política de Lefort continua girando em torno à legitimidade, é verdade também que o alvo não é mais o poder fático, mas as "lutas de contestação", as lutas que escapam ao controle do Estado. Dizíamos que “a judicialização da política e a politização do judiciário” põem em primeiro plano a operacionalidade do "Estado de Direito", mas que, todavia, acima disso, importa investigar a relação entre poder e direito, e que, assim, escapamos ao "estadocentrismo" e aos prejuízos da teoria da soberania, consubstanciados na legitimidade do poder e na obrigação legal da obediência. $\mathrm{O}$ direito aparece aqui a serviço do poder, como mostra Foucault. Lefort, por sua vez, parece recuperar uma dimensão do direito - ignorada por Foucault - em que esse se coloca agora, face ao poder, como um "foco indomável", em uma "exterioridade indelével” (LEFORT 1983, p.53): é o poder que deve finalmente conformar-se ao direito, sob o risco abismar-se na violência.

\section{'Notas de fim'}

$<$ ?> - Sobre isso, diz o jovem Marx, em 1843: “(...) uma classe que tenha cadeias radicais, (...) uma classe na sociedade civil que não seja uma classe da sociedade civil, (...) um estamento que seja a dissolução de todos os estamentos, (...) uma esfera que possua caráter universal porque os seus sofrimentos são universais e que não exige uma reparação particular porque o mal que lhe é feito não é um mal particular, mas o mal em geral, que já não possa exigir um título histórico, mas apenas o título humano (...) uma esfera que não pode emancipar-se a si mesma nem se emancipar de todas as outras esferas da sociedade sem emancipá-las a todas (...). A dissolução da sociedade, como classe particular, é o proletariado” in Marx, K. Crítica da filosofia do direito de Hegel (Introdução). Boitempo, 2005, p.156..

$<$ ?> - "É ainda Kant que finalmente encontramos no conceito da revolução como ação absoluta" (Idem, ibidem, p.321).

$<$ ?> - Veremos adiante de onde vem essa permanência do simbólico.

<?> - O problema do "espontâneo" e "natural”: em Hume, o acordo implica um ajuste, ele não vem inscrito nos próprios termos, sempre diferentes. O acordo é, portanto, "artificial”, devendo ser fixado pelas vantagens que traz. Mas ele não é fruto de um acordo explícito, como um contrato. Daí porque "artificial” não se opõe a "natural". 


\section{REFERÊNCIAS BIBLIOGRÁFICAS}

FAUSTO, R. 2018. "Claude Lefort e a crítica de A propósito da questão judaica de Marx: dialética e ideologia” in Revista Discurso, v.48, n.1.

FLYNN, B. 2005. The Philosophy of Claude Lefort: Interpreting the political. Evanston : Northwestern University Press.

FOUCAULT, M. 2001a. “Cours du 14 janvier 1976” in Dits et écrits II. Txt.194. Paris : Quarto Gallimard. Gallimard. . 2001b. "Entretien avec Michel Foucault" in Dits et écrits II. Txt.192. Paris : Quarto .2005. Em defesa da sociedade. São Paulo : Martins Fontes.

LEBRUN, G. 1981. O que é poder. São Paulo : Brasiliense.

.2006. "Hobbes aquém do liberalismo" in A filosofia e sua história. São Paulo : Cosac \& Naify.

LEFORT, C. 1972. Le travail de l'oeuvre. Machiavel. Paris : Gallimard.

1978. Sur une colonne absente. Écrits autour de Merleau-Ponty. Paris : Gallimard.

. 1979. As formas da história. São Paulo : Brasiliense.

1983. A invenção democrática. São Paulo : Brasiliense.

1991. Pensando o político. Rio de Janeiro : Paz e Terra.

MARX, K. 2005. Crítica da filosofia do direito de Hegel. São Paulo : Boitempo.

MERLEAU-PONTY, M. 1981. Signes. Paris : Gallimard.

2000. Les aventures de la dialectique. Paris : Gallimard.

NEVES, JOSÉ L. B. 2016. "Merleau-Ponty e o marxismo: política e filosofia da história” in Revista Dois

Pontos, v.13,n.1. 